\title{
Fourth (2012) UK purine club annual symposium report
}

\author{
Samuel J. Fountain
}

Published online: 4 July 2013

(C) Springer Science+Business Media Dordrecht 2013

The fourth UK Purine Club annual symposium was held in Norwich, Norfolk in November 2012. Delegates from across the UK travelled to convene at this "fine city" and the Assembly House- - G Grade I listed building situated in the heart of Norwich. Oral communications took place in the Music Room, a room in which the composer and pianist Franz Listz performed in 1840. Generous financial support from Tocris, Stratech, BMG Labtech, Abcam Biochemicals and New England Biolabs helped us hold the event in such an impressive venue.

The meeting comprised three plenary lectures, three oral communication sessions (chaired by Richard Evans, Heather Wilson, Ruth Murrell-Lagnado, Susanna Hourani, Tim Arnett and Keith Brain) and some excellent posters by early stage and established researchers. The meeting opened with a plenary lecture by Professor R. Alan North FRS (Manchester) - an inspiring talk and tour de force of P2X receptor structure-function " 20 years of $\mathrm{P} 2 \mathrm{X}$ ". This was also an occasion to mark Professor North's seminal contribution to the field of purinergic signaling and indeed ion channel biology in general. After lunch and posters, we were treated to an insight into pyrimidinergic signaling in a plenary lecture by Professor Antony Galione FMedSci (Oxford). We learnt about the signaling and physiology of NAADP, an intracellular ultrapotent calcium mobilizing second messenger. Professor Nick Dale (Warwick) completed the plenary lectures with an enthusiastic talk on purine biosensors and their medical applications. Professor Geoff Burnstock FRS announced the student winners of the poster competition (Lucy Robinson; Cambridge) and best oral communication (Stuart Hanmer; Cardiff). Professor Burnstock closed by leaving delegates with insight into the expanding world of purinergic signaling.

We enjoyed hosting the meeting in Norwich and are happy to see the UK Purine Club continuing with such momentum. We hand over to Ruth Murrell-Lagnado who will host the $5^{\text {th }}$ UK Purine Club meeting in Cambridge 2013-Best wishes to Ruth and her team!

Samuel J. Fountain
S. J. Fountain $(\bowtie)$

School of Biological Sciences, University of East Anglia,

Norwich Research Park NR4 7TJ, UK

e-mail: S.J.Fountain@uea.ac.uk 